\title{
Effect of some Natural Treatments on Vegetative Growth and Leaf Chemical Composition of Squash Plants Growing Under Cold Conditions. Wanas, A. L. ${ }^{1}$; M. S. Serag ${ }^{2}$; A. S. Abd Elhamied ${ }^{3}$ and Hanan O. Abd Elaziz ${ }^{1}$ \\ ${ }^{1}$ Dept. of Bot., Fac. of Agric., Damietta Univ., Egypt. \\ ${ }^{2}$ Dept. of Bot. and Microbiology., Fac. of Sci., Damietta Univ., Egypt. \\ ${ }^{3}$ Dept. of Soil., Fac. of Agric., Damietta Univ., Egypt.
}

\section{ABSTRACT}

Growth of squash plants cv. Eskandarani during winter seasons of 2016 and 2017 under outdoor conditions was significantly enhanced by application of some natural treatments, i.e. seed cold hardening $(\mathrm{SCH})$ at $-1^{\circ} \mathrm{C}$ for $12 \& 24$ hours of exposure period as seed pre-sowing treatments, and salicylic acid (SA) at $100 \& 200 \mathrm{ppm}$, the mineral nutrients (Ca at $250 \& 500 \mathrm{ppm}$ and $\mathrm{Zn}$ at 50 and $100 \mathrm{ppm}$ and the natural extracts (GCE at $50 \& 100 \mathrm{~g} / 1$ and LRE at $5 \& 10 \mathrm{~g} / \mathrm{l})$ as seed soaking then foliar spray treatments. Since, significant increases in stem length and diameter, leaves number and total area / plant, as well as fresh and dry weights of roots, stems and leaves were obtained with all applied treatments. Meanwhile, significant reduction in the assimilation rate was existed. Besides, different applied treatments obviously increased photosynthetic pigments, NPK, sugars, total carbohydrates and crude protein contents in leaves of the treated plants compared with those of untreated ones. Increases were in parallel to the applied level of SCH, GCE, LRE, SA, Ca and $\mathrm{Zn}$. In addition, GCE at $100 \mathrm{~g} / \mathrm{l}$ was the most pronounced treatment in this respect, followed by SA at $200 \mathrm{ppm}, \mathrm{LRE}$ at $10 \mathrm{~g} / \mathrm{l}, \mathrm{Ca}$ at $500 \mathrm{ppm}, \mathrm{Zn}$ at $100 \mathrm{ppm}$ and $\mathrm{SCH}$ at -1 for 24 hours of exposure period in descending order. Therefore, the present study strongly admit the use of natural garlic and licorice extracts, salicylic acid and some mineral nutrients as seed pre-sowing treatments not only to improve growth and productivity of squash plants during winter months under outdoors conditions but also to avoid all cautions (regarding both environment and human consumption) for inserting greenhouses production in the agricultural system.

\section{INTRODUCTION}

Summer Squash, vegetable marrow, (Cucurbita pepo, L.) is one of the most important economic fruitvegetables grown in Egypt which cultivated all over the year, outdoor in summer and indoor (either in greenhouses or in tunnels) in the winter season. It is one of warm requiring vegetable crops and it does not tolerate either cooler or frosty weather during germination and different stages of growth and development without indoor protection. Squash is injured when exposed to nonfreezing temperature, i.e., below $12^{\circ} \mathrm{C}$ (Rab and Saltveit, 1996). Under local conditions, similar findings of the adverse effects of natural cold stress on growth, flowering and yielding of squash plants were obtained by Abd EL-Dayem et al., 2000. The exposure of chilling-sensitive plants to low temperature causes disturbances in all physiological processes as water regime, mineral nutrition, photosynthesis, respiration and metabolism. Inactivation of metabolism, observed at chilling of chilling-sensitive plants is a complex function of both temperature and duration of exposure (Lukatkin et al., 2012).

Low temperature represents the main adverse factor for production of squash in winter and early summer plantings under open field conditions. So, great attention had been focused on the possibility to improve the ability of vegetables to tolerate cold stress. Among these treatments, seed cold hardening (Abd EL-Dayem et al., 2000), use of natural extracts of yeast and carrot (Wanas, 2006) and some nutrient elements (Wanas, 2007a and Mady, 2014).

On the other hand, it was demonstrated that all environmental stresses, cold, heat, salt, etc., either accelerate the formation of toxic oxygen free radicals (ROS) levels within plant tissues or impair the normal defense mechanisms that protect tissues from ROS toxic effect. Such stresses induce higher $\mathrm{O}_{2}$ photo- reduction within chloroplasts or electron transport disturbance, and donation of an electron to $\mathrm{O}_{2}$ within mitochondria all led to the generation of toxic ROS (Mckerise et al., 1996). Those $\operatorname{ROS}\left(\mathrm{H}_{2} \mathrm{O}_{2}^{-}, \mathrm{OH}^{-}, \mathrm{O}_{2}^{-} \ldots \ldots.\right)$ damaged chloroplast, reduced carbohydrates synthesis and exportation and hastened oxygen senescence (Dickinson et al., 1991), attacked cell membranes leading to their degradation and leakage of cell solutes, denaturation of protein and enzymes, damage of nucleic acids, degradation of chlorophyll and suppression of all metabolic processes, finally senescence and death of cells and tissues (Cakmak and Marschner, 1992).

Antioxidants or oxygen free radical scavengers were exogenously applied to protect against adverse effects of environmental, oxidative stress such as citric acid, carotenoids, ascorbate, $\alpha$-tocopherol, glutathione, vitamins and some nutrients (Fathy et al., 2000 and Wanas, 2006 \& 2007a and Mady, 2014).

Cold hardening is the process by which plants adjust their metabolism for survival at low temperature. A dramatic manifestation of cold hardening is the increased tolerance to freezing demonstrated by many plants after extended exposure to low, non-freezing temperatures (Palva, 1993). In this respect, seed germination, vegetative growth, flowering, fruit yield of squash and some other cucurbits and fruit quality have been improved by the presowing low-temperature treatment (Wien, 1997 and Abd El-Dayem et al., 2000).

Salicylic acid (SA), is a phenolic compound and considers as a phytohormone. It plays an important role in the regulation of plant growth and development such as seed germination, photosynthetic and growth rates, flowering, fruit set and fruit ripening (Klessing and Malamy, 1994, Khan et al., 2003 and Mady, 2014).

Calcium has attracted much interest in plant physiology because of its function as a second messenger in signal conduction between the environmental factors (such as low temperature) and plant responses in terms of growth and development. It is an essential plant macronutrient with key structural and signaling roles. Calcium ions $\left(\mathrm{Ca}^{2+}\right)$ act as an osmoticum within vacuoles; a stabilizing element of membranes; a strengthening agent in cell walls and a secondary messenger for a multitude of signals (Dodd et al., 2010 and Cacho et al., 2013).

Zinc is a microelements essential for the growth and development of plants and plays a functional catalytic (Vallee and Auld, 1990) and structural role in enzyme reactions (Ulsusmiya and Muto, 1993). Moreover, it plays a key role in controlling (scavenging) both generation and detoxification of free oxygen radicals in which that lead to 
potentially prevention of their adverse consequences, i.e. damaging of membrane lipids, photo-oxidation in chloroplasts, disturbances electron transport in mitochondria, electrolyte leakage from vacuoles and distraction of protein synthesis in ribosomes (Marschner, 1995 and Mckerise et al., 1996).

Garlic cloves extract (GCE) suggested participating a beneficial role during vegetative and reproductive growth through improving flowers formation and their set of some plants due to its enhancement of endogenous auxins, gibberellins and cytokinins level and carbohydrates accumulation (El-Desouky et al., 1988), beside its stimulatory effects on cell division and enlargement (Wanas et al., 1998), protein synthesis and chlorophyll formation (Seham, Aly 2002 and Wanas, 2006). Furthermore, garlic cloves are highly rich in amino acids, antibiotics, antioxidants (phenolic compounds, vitamin B complex and vitamin $\mathrm{C}$ and flavonoids), sugars and minerals especially P, K and Se (Lanzotti et al., 2014 and Mardomi, 2017).

Licorice root extract (LRE) is a rich source of biologically active compounds such as phenols and flavonoids. Phenolic compounds are very essential for plants because of their radical scavenging capacity due to the presence of hydroxyl group. They belong to a class of antioxidants which act as free radicals inhibitors (Elmastas et al., 2006). Foliar application with licorice extract caused a significant increase in some growth parameters (plant height, number of leaves/plant and shoot dry weight), total chlorophyll content and total soluble carbohydrates compared with those of the untreated plants (Faraj and Ghaloom, 2012). This may be due to licorice extract contains some important compounds which accumulated in large amounts such as triterpene saponins (including glycyrrhizin), mevalonic acid which has similar effect to $\mathrm{GA}_{3}$ in improving the growth of the plants (Rossi, 1999 and Arystanova et al., 2001).

The present study aimed to alleviate the adverse effects of low temperature and its probable accompanied oxidative stress on squash plants towards improving their growth during winter months by using seed cold hardening, salicylic acid, some nutrient elements (calcium and zinc) and natural extracts of garlic cloves and licorice roots as alternative possibility for using greenhouses production.

\section{MATERIALS AND METHODS}

Two pot experiments were conducted out-doors at the Experimental Farm of El-Serw Agricultural Research Station, Damietta Governorate, Ministry of Agriculture, Egypt during two successive winter seasons of 2016 and 2017. Squash (Cucurbita pepo, L.) cultivar Eskandarani (that known to be cultivated in Egypt in warm seasons) was taken as a botanical material in this work. Seeds were obtained from the Egyptian Agricultural Res, Center, Ministry of Agric., ARE.

\section{1-Experiment design:}

This study was performed to induce cold tolerability in squash plants by using seed cold hardening, salicylic acid, calcium, zinc and natural extracts of garlic cloves and licorice roots for improving growth and productivity under open field at low temperature during winter months. Thus, to achieve the aim of this study an experimental design included thirteen treatments as follows:

1- Distilled water as a control treatment.

2- Seed hardening with low temperature $(\mathrm{SCH})$ at $-1{ }^{\circ} \mathrm{C}$ for two exposure periods ( $12 \& 24$ hours).

3- Salicylic acid (SA) at concentrations of $100 \& 200 \mathrm{ppm}$

4- Calcium (Ca) at concentrations of $250 \& 500 \mathrm{ppm}$.

5- Zinc (Zn) at concentrations of $50 \& 100 \mathrm{ppm}$.

6- Licorice roots extract (LRE) at concentrations of $5 \&$ $10 \mathrm{~g} / 1$.

7- Garlic cloves extract (GCE) at concentrations of 50 \& $100 \mathrm{~g} / 1$.

Preparation of the assigned treatments:

-Seed cold hardening treatments:

Seed cold hardening was done according to Abd El-Dayem et al., 2000. Seeds were soaked in distilled water and kept for 6 hours to swell at room temperature (22 $\left.\pm 2{ }^{\circ} \mathrm{C}\right)$. After swelling, the seeds were taken out of the water and divided into two equal groups on two plastic plates with two layers filter papers. The first plate with seeds was kept for 12 hours in freezer regulated and calibrated at $-1{ }^{\circ} \mathrm{C}$. Meanwhile, the second plate with the second group of seeds was kept for 24 hours at the same temperature.

- Salicylic acid treatments:

A certain weight $(1 \mathrm{~g})$ of salicylic acid was solved in $100 \mathrm{ml}$ of $85 \%$ of methanol alcohol then completed with distilled water to one litter to make up stock solution of salicylic acid at concentration $1000 \mathrm{ppm}$. Then 100 and 200 $\mathrm{ml}$ of stock solution were separately taken and completed with distilled water to one liter for preparing, the applied concentrations of salicylic acid, i.e., 100 and 200 ppm, respectively.

\section{- Calcium treatments:}

A stock solution of calcium at concentration 1000 ppm was prepared by solving $25 \mathrm{~g}$ from calcium citrate (20 $\% \mathrm{Ca}$ ) in 5 litters of distilled water. Then 250 and $500 \mathrm{ml}$ of stock solution were separately taken, putted in volumetric flask and completed with distilled water to one litter to make up the applied calcium concentrations, i.e., 250 and 500 ppm, respectively.

\section{- Zinc treatments:}

A certain weight $(7.1 \mathrm{~g})$ of chelated zinc $(14 \% \mathrm{Zn})$ was solved in one litter of distilled water to make up stock solution of zinc at concentration $1000 \mathrm{ppm}$. Then 50 and $100 \mathrm{ml}$ of stock solution were separately taken, putted in volumetric flask and completed with distilled water to one litter for preparing the applied zinc concentrations, i.e., 50 and 100 ppm, respectively.

\section{- Licorice roots extract (LRE):}

A stock licorice (Glycyrrhiza globra l.) extract was prepared according to the method described by Almehemdi et al., 2011). $100 \mathrm{~g}$ of licorice root powder was added to $200 \mathrm{ml}$ distilled water in a dark bottle and kept inside incubator at $50^{\circ} \mathrm{C}$ for 24 hours. The mixture was transferred into an electrical mixer for one minute. Then the extract was filtered by filter paper (Whattman No. 1) using the suppression Bouchner fennel to get rid of plant residues in one litter volumetric flask. Process was repeated several times to get the right amount. The stock solution (100 g / litter was kept in a refrigerator at a 
temperature of $5 \pm 2^{\circ} \mathrm{C}$ until the preparation of concentrations used in this study i.e., 5 and $10 \mathrm{~g} /$ litter.

- Garlic cloves extract (GCE):

Fresh mature garlic cloves were blended in distilled water (200 g cloves/l liter H2O), frozen and thawed two times, then filtered. The filtrate was used for preparation of different garlic extract concentrations, i.e., 50 and $100 \mathrm{~g} / \mathrm{l}$. Such technique of garlic preparation modified after ElDesouky et al., (1988).

The assigned nutrient elements, natural extracts and salicylic acid with their levels as well as distilled water were applied as seed soaking materials for 6 hours at room temperature $\left(22 \pm 2{ }^{\circ} \mathrm{C}\right)$ and as a foliar spray at 40 days after sowing, besides two cold hardening treatments $(12$ \& 24 hours of exposure periods at $-1^{\circ} \mathrm{C}$ ) were applied only as seed pre-sowing treatments.

Pots of $30 \mathrm{~cm}$ in diameter, filled with $10 \mathrm{~kg}$ mixture of clay and sand $(1: 1 \mathrm{v} / \mathrm{v})$. Then pre-sowing treated seeds of squash cultivar with different assigned treatments were sown ( 20 pots for each treatment and 5 seeds/ pot) at the $5^{\text {th }}$ of January for 2016 and 2017 seasons. After seedlings emergence (week after sowing) seedlings were thinned to one plant per pot. The experiment was performed as a randomized complete - block design system with four replicates, each one 5 pots. In both seasons, the normal agricultural practices of growing squash were followed up as recommended.

\section{2-Sampling date and collecting data:}

-Vegetative growth characters:

Four plants were randomly chosen from each treatment at 65 (flowing stage) days after sowing in both seasons to estimate some growth parameters as roots size $\left(\mathrm{cm}^{3}\right)$, roots fresh and dry weights $(\mathrm{g}) /$ plant, stems length and diameter $(\mathrm{cm})$, stem fresh and dry weights $(\mathrm{g}) /$ plant, number of leaves/plant, stalk length of the third basal leaf $(\mathrm{cm})$, leaves fresh and dry weights $(\mathrm{g}) /$ plant and total leaf area $\left(\mathrm{cm}^{2}\right) /$ plant. Stem diameter was measured at the first internode and the root size was determined according to the proposition of Hanson and Churchill (1968). While total leaf area $\left(\mathrm{cm}^{2}\right)$ / plant was determined using the disk method as described by Derieux et al., (1973). Also, the assimilation rate (A.R.) according to Wareing and Phillips (1981) using the following equation:

\section{A.R. $=$ Total leaf area $\left(\mathrm{cm}^{2}\right) /$ plant \\ Total dry weight of leaves (g) / plant}

-Photosynthetic pigments:

Chlorophyll a, b and carotenoids were colorimetrically determined in squash leaves at 65 days after sowing in both seasons according to the method described by Inskeep (1985) and calculated as $\mathrm{mg} / \mathrm{g}$ fresh weight.

- Chemical analysis in leaves:

Samples from squash leaves at 65 days after sowing were taken to determine total carbohydrates (Dubois et al., 1956), total and reducing sugars (Thomas and Dutcher, 1924), total nitrogen (Horneck and Miller, 1998), phosphorus (Sandell, 1950), potassium (Horneck and Hanson, 1998) and calcium and magnesium (Jackson, 1967). Also, crude protein was calculated according to A.O.A.C (1990) using the following equation:

Crude protein $=$ total nitrogen $X 6.25$

\section{3-Statistical analysis.}

Data of vegetative growth were subjected to statistical analysis according to Snedecor and Cochran (1989) using L.S.D. test at 0.05 level.

\section{RESULTS AND DISCUSSION}

\section{1- Growth parameters:}

Data presented in Tables $(1 \& 2)$ clearly show that different assigned treatments significantly increased the growth parameters of roots (size, fresh and dry weights), stems (length, diameter, fresh and dry weights) and leaves (number, petiole length and diameter, leaf area, fresh and dry weights) estimated at 65 days after sowing compared with those of the untreated plants in both seasons of this study. The most pronounced effect in this respect was shown with garlic extract (GCE) followed by salicylic acid (SA) then seed cold hardening (SCH), or calcium (ca) meanwhile, zinc (Zn) or licorice root extract (LRE) gave the lowest increment compared with the control. Besides, the high concentration of all applied substances gave the highest values of all mentioned vegetative growth parameters as compared with the low one. Also, the seed pre-sowing hardening at $-1{ }^{\circ} \mathrm{C}$ was more effective when applied for 24 hours than another exposure period (12 hours) at the same temperature level $\left(-1^{\circ} \mathrm{C}\right)$.

Table 1. Effect of seed cold hardening, salicylic acid, calcium, zinc, garlic extract and licorice root extract on some growth parameters of squash plants at 65 days after sowing (during flowering stage) in 2016 winter season.

\begin{tabular}{|c|c|c|c|c|c|c|c|c|c|c|c|c|c|c|c|}
\hline \multicolumn{2}{|c|}{ Characteristics } & \multicolumn{3}{|c|}{ Roots } & \multicolumn{4}{|c|}{ Stem } & \multicolumn{6}{|c|}{ Leaves } & \multirow[b]{2}{*}{$\begin{array}{c}\text { A.R. } \\
\mathrm{cm}^{2} / \mathrm{g}\end{array}$} \\
\hline \multicolumn{2}{|c|}{ Treatments } & $\begin{array}{c}\text { Size } \\
\left(\mathrm{cm}^{3}\right)\end{array}$ & $\begin{array}{c}\text { Fresh } \\
\text { weight } \\
\text { (g)/ } \\
\text { plant }\end{array}$ & $\begin{array}{c}\text { Dry } \\
\text { weight } \\
\text { (g)/ } \\
\text { plant }\end{array}$ & $\begin{array}{c}\text { Length I } \\
\text { (cm) }\end{array}$ & $\begin{array}{l}\text { Diameter } \\
(\mathrm{cm})\end{array}$ & $\begin{array}{c}\text { Fresh } \\
\text { weight } \\
\text { (g)/ } \\
\text { plant }\end{array}$ & $\begin{array}{c}\text { Dry } \\
\text { weight } \\
\text { (g)/ } \\
\text { plant }\end{array}$ & $\begin{array}{l}\text { No./ } \\
\text { Plant }\end{array}$ & $\begin{array}{l}\text { Petiole } \\
\text { length o } \\
\text { (cm) }\end{array}$ & $\begin{array}{l}\text { Petiole } \\
\text { diameter } \\
(\mathrm{cm})\end{array}$ & $\begin{array}{c}\text { Total } \\
\text { leaf area } \\
\left(\mathrm{cm}^{2}\right) / \\
\text { plant }\end{array}$ & $\begin{array}{c}\text { Fresh } \\
\text { weight } \\
\text { (g)/ } \\
\text { plant }\end{array}$ & $\begin{array}{c}\text { Dry } \\
\text { weight } \\
\text { (g)/ } \\
\text { plant }\end{array}$ & \\
\hline \multicolumn{2}{|l|}{$\overline{\text { Control }}$} & 167.50 & 7.94 & 2.96 & 5.93 & 0.96 & 5.93 & 0.68 & 9.00 & 11.56 & 0.61 & 661 & 36.27 & 3.85 & 171.79 \\
\hline $\mathrm{SCH}$ & 12 hours & 182.50 & 13.65 & 3.92 & 7.96 & 1.06 & 9.35 & 1.06 & 11.00 & 18.56 & 0.90 & 1473 & 70.81 & 9.37 & 151.39 \\
\hline$\left(-1^{\circ} \mathrm{C}\right)$ & 24 hours & 185.75 & 17.03 & 5.55 & 8.27 & 1.11 & 10.18 & 1.39 & 11.50 & 18.69 & 1.00 & 17345 & 82.47 & 12.21 & 142.2 \\
\hline \multirow{2}{*}{ SA } & $100 \mathrm{ppm}$ & 184.25 & 13.51 & 4.05 & 7.8 & 1.06 & 10.11 & 1.22 & 10.75 & 19.28 & 0.94 & 1124 & 91 & 7.04 & 159.79 \\
\hline & 200 ppm & 188.00 & 17.34 & 5.29 & 8.43 & 1.16 & 11.64 & 1.29 & 12.00 & 20.28 & 0.98 & 1450 & 84.33 & 9.27 & 156.43 \\
\hline \multirow{2}{*}{$\mathrm{Ca}$} & $250 \mathrm{ppm}$ & 183.25 & 12.56 & 4.19 & 7.27 & 1.16 & 8.05 & 1.16 & 10.75 & 14.95 & 0.91 & 1017 & 66.47 & 6.65 & 152.93 \\
\hline & & 187.75 & 17.26 & 5.35 & 8.10 & 1.18 & 9.49 & 1.26 & 11.75 & 19.56 & 1.06 & 1273 & 75.46 & 8.78 & 145.12 \\
\hline \multirow{2}{*}{$\mathrm{Zn}$} & $50 \mathrm{ppm}$ & 181.75 & 12.61 & 3.86 & 7.51 & 1.03 & 7.95 & 0.95 & 11.50 & 18.56 & 0.89 & 1041 & 66.08 & 6.45 & 161.44 \\
\hline & $100 \mathrm{ppm}$ & 184.00 & 15.20 & 5.19 & 8.24 & 1.11 & 8.84 & 0.98 & 11.75 & 19.56 & 1.00 & 1070 & 67.93 & 7.10 & 150.78 \\
\hline \multirow{2}{*}{ GCE } & $50 \mathrm{~g} / 1$ & 184.00 & 15.00 & 4.98 & 7.17 & 1.06 & 10.95 & 1.33 & 11.25 & 19.31 & 1.06 & 1648 & 75.94 & 11.59 & 142.21 \\
\hline & $100 \mathrm{~g} / 1$ & 190.50 & 17.92 & 5.95 & 8.29 & 1.12 & 12.23 & 1.47 & 12.00 & 20.84 & 1.10 & 1877 & 92.35 & 13.87 & 135.36 \\
\hline \multirow{2}{*}{ LRE } & $5 \mathrm{~g} / 1$ & 179.50 & 11.03 & 3.15 & 6.49 & 1.01 & 8.70 & 0.96 & 10.75 & 16.56 & 0.92 & 1018 & 71.44 & 6.75 & 150.82 \\
\hline & $10 \mathrm{~g} / 1$ & 182.25 & 14.22 & 4.29 & 8.08 & 1.06 & 9.12 & 1.06 & 11.50 & 17.28 & 0.96 & 1146 & 71.50 & 7.71 & 148.73 \\
\hline \multicolumn{2}{|c|}{ LSD at 0.05} & 5.22 & 0.40 & 0.14 & 0.44 & 0.04 & 0.62 & 0.08 & 0.63 & 0.57 & 0.07 & 87.54 & 4.38 & 0.78 & 6.16 \\
\hline
\end{tabular}

Abbreviations: SCH = Seed cold hardening, SA = Salicylic acid, Ca $=$ Calcium, Zn $=$ Zinc, LRE $=$ Licorice root extract, GCE $=$ Garlic cloves extract and A.R. = Assimilation rate. 
Wanas, A. L. et al.

Table 2. Effect of seed cold hardening, salicylic acid, calcium, zinc, garlic extract licorice root extract on some growth parameters of squash plants at 65 days after sowing (during flowering stage) in 2017 winter season.

\begin{tabular}{|c|c|c|c|c|c|c|c|c|c|c|c|c|c|c|c|}
\hline \multirow{2}{*}{\multicolumn{2}{|c|}{ Treatments }} & \multicolumn{3}{|c|}{ Roots } & \multicolumn{4}{|c|}{ Stem } & \multicolumn{6}{|c|}{ Leaves } & \multirow[b]{2}{*}{$\begin{array}{c}\text { A.R. } \\
\mathrm{cm}^{2} / \mathrm{g}\end{array}$} \\
\hline & & $\begin{array}{c}\text { Size } \\
\left(\mathrm{cm}^{3}\right)\end{array}$ & $\begin{array}{c}\text { Fresh } \\
\text { weight } \\
\text { (g)/ } \\
\text { plant }\end{array}$ & $\begin{array}{c}\text { Dry } \\
\text { weight } \\
\text { (g)/ } \\
\text { plant }\end{array}$ & $\begin{array}{l}\text { Length } \\
\text { (cm) }\end{array}$ & $\begin{array}{c}\text { Diameter } \\
(\mathrm{cm})\end{array}$ & $\begin{array}{c}\text { Fresh } \\
\text { weight } \\
\text { (g)/ } \\
\text { plant }\end{array}$ & $\begin{array}{c}\text { Dry } \\
\text { weight } \\
\text { (g)/ } \\
\text { plant } \\
\end{array}$ & $\begin{array}{l}\text { No./ } \\
\text { plant }\end{array}$ & $\begin{array}{c}\text { Petiole } \\
\text { length } \\
(\mathrm{cm})\end{array}$ & $\begin{array}{c}\text { Petiole } \\
\text { diameter } \\
\text { (cm) }\end{array}$ & $\begin{array}{c}\begin{array}{c}\text { Total } \\
\text { leaf area } \\
\left(\mathrm{cm}^{2}\right) / \\
\text { plant }\end{array} \\
\end{array}$ & $\begin{array}{c}\begin{array}{c}\text { Fresh } \\
\text { weight } \\
\text { (g)/ } \\
\text { plant }\end{array} \\
\end{array}$ & $\begin{array}{c}\text { Dry } \\
\text { weight } \\
\text { (g)/ } \\
\text { plant }\end{array}$ & \\
\hline Control & & 161.00 & 6.86 & 2.61 & 5.39 & 0.92 & 5.57 & 0.64 & 9.25 & 11.06 & 0.58 & 625 & 30.39 & 3.81 & 164.18 \\
\hline $\mathrm{SCH}$ & 12 hours & 181.75 & 11.88 & 3.15 & 7.11 & 0.92 & 7.74 & 0.93 & 10.75 & 17.78 & 0.86 & 952 & 66.99 & 6.24 & 152.64 \\
\hline$\left(-1^{\circ} \mathrm{C}\right)$ & 24 hours & 183.50 & 14.56 & 3.76 & 7.56 & 0.92 & 8.11 & 0.95 & 11.50 & 19.13 & 0.96 & 1293 & 75.39 & 8.56 & 151.07 \\
\hline \multirow{2}{*}{ SA } & $100 \mathrm{ppm}$ & 181.25 & 12.16 & 3.34 & 7.79 & 1.03 & 8.26 & 0.88 & 10.50 & 18.84 & 0.96 & 1089 & 64.94 & 7.07 & 154.10 \\
\hline & $200 \mathrm{ppm}$ & 184.25 & 15.39 & 4.33 & 7.83 & 1.11 & 9.83 & 0.99 & 10.75 & 19.94 & 1.00 & 1121 & 73.10 & 7.88 & 142.30 \\
\hline \multirow{2}{*}{$\mathrm{Ca}$} & $250 \mathrm{ppm}$ & 182.25 & 12.03 & 3.49 & 6.98 & 1.04 & 8.62 & 0.86 & 10.25 & 14.28 & 0.87 & 956 & 60.30 & 6.61 & 144.68 \\
\hline & $500 \mathrm{ppm}$ & 183.75 & 14.64 & 4.24 & 7.48 & 1.13 & 8.99 & 0.96 & 10.75 & 19.13 & 1.07 & 1028 & 66.91 & 6.92 & 148.59 \\
\hline \multirow{2}{*}{$\mathrm{Zn}$} & $50 \mathrm{ppm}$ & 178.25 & 10.36 & 3.05 & 7.14 & 1.00 & 8.32 & 0.83 & 10.75 & 18.13 & 0.70 & 968 & 52.98 & 6.19 & 156.38 \\
\hline & $100 \mathrm{ppm}$ & 181.00 & 12.96 & 4.18 & 7.81 & 1.11 & 8.83 & 0.85 & 11.00 & 19.15 & 0.89 & 1023 & 60.39 & 6.61 & 154.77 \\
\hline \multirow{2}{*}{ GCE } & $50 \mathrm{~g} / 1$ & 182.00 & 12.06 & 3.53 & 7.06 & 1.03 & 8.74 & 0.94 & 11.25 & 19.53 & 0.89 & 1071 & 67.72 & 7.17 & 149.46 \\
\hline & $100 \mathrm{~g} / 1$ & 184.50 & 17.73 & 4.59 & 7.72 & 1.11 & 10.39 & 1.05 & 11.75 & 20.41 & 1.00 & 1254 & 78.89 & 8.88 & 141.28 \\
\hline \multirow{2}{*}{ LRE } & $5 \mathrm{~g} / 1$ & 179.50 & 9.66 & 3.50 & 6.11 & 1.01 & 8.25 & 0.83 & 10.75 & 16.16 & 0.88 & 1035 & 55.15 & 6.77 & 152.97 \\
\hline & $10 \mathrm{~g} / 1$ & 181.00 & 11.90 & 3.59 & 7.34 & 1.02 & 8.88 & 0.87 & 11.25 & 16.84 & 1.00 & 1226 & 64.60 & 8.13 & 150.83 \\
\hline \multicolumn{2}{|c|}{ LSD at 0.05} & 4.38 & 0.43 & 0.17 & 0.33 & 0.06 & 0.36 & 0.04 & 0.78 & 0.86 & 0.08 & 104.69 & 4.52 & 0.57 & 4.04 \\
\hline
\end{tabular}

Abbreviations: $\mathbf{S C H}=$ Seed cold hardening, $\mathbf{S A}=$ Salicylic acid, $\mathbf{C a}=$ Calcium, $\mathrm{Zn}=$ Zinc, $\mathbf{L R E}=\mathbf{L i c o r i c e}$ root extract, $\mathbf{G C E}=\mathbf{G a r l i c}$ cloves extract and A.R. = Assimilation rate.

Here, of interest that some of the growth parameters in case of GCE, SA, SCH, and calcium treatments reached more than two times of control. Of these are leaves dry weight and total leaf area/ plant (Tables, $1 \& 2$ and Figs., $1 \& 2$ ). Besides, data in these tables indicated that increment each of total leaves number and total leaf area/ plant was reversed upon the total leaf dry weight/ plant, which means that photosynthetic area and its activity were increased, hence that could be reflected on the final fruit yield.
Moreover, the roots dry weight was obviously increased as affected by different applied treatments, to reach about two times of the control value with GCE at $100 \mathrm{~g} / 1$ during the first season. That means that more dry matter was directed to be accumulated in roots and hence vigorous root system accompanied with high efficiency of water, minerals and nutrients uptake being attained. That could be also reflected on further growth stages.

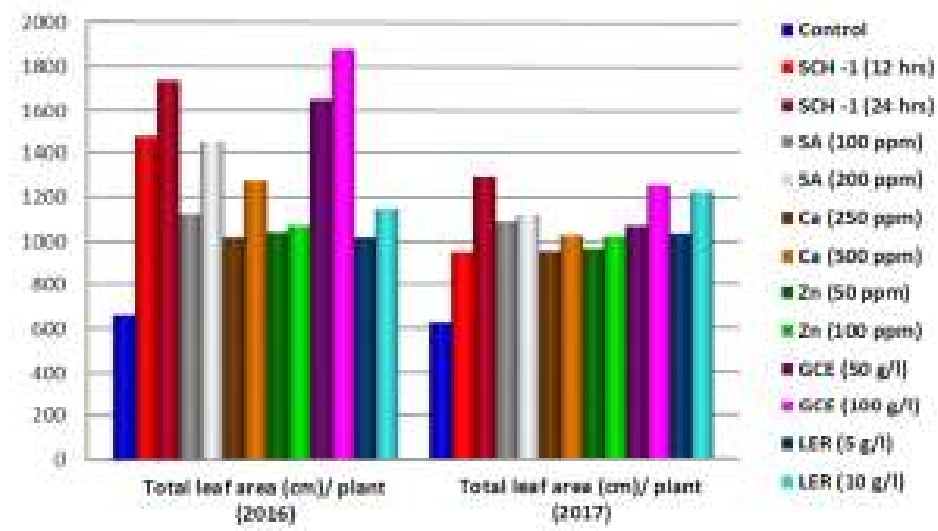

Fig. 1. Shows the effect of different applied treatments on the total leaf area (cm) per plant at 65 days after sowing during 2016 \& 2017 growing seasons.

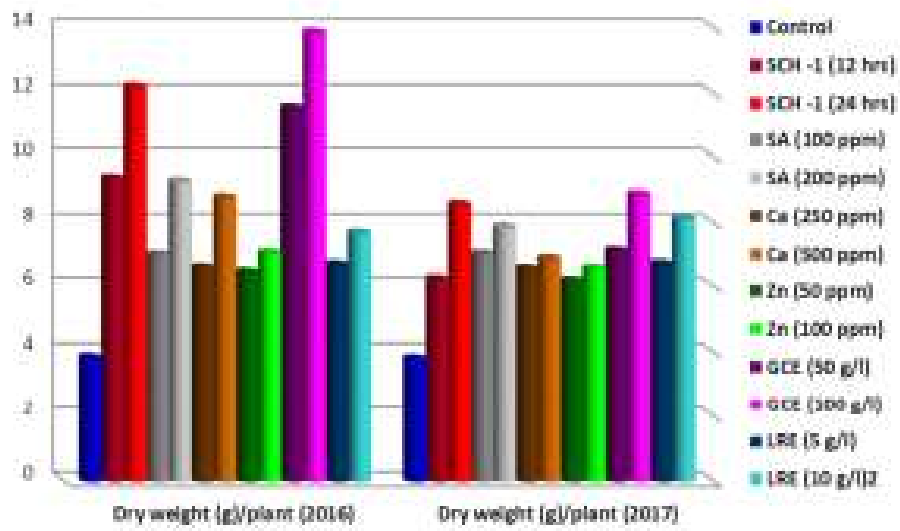

Fig. 2. Shows the effect of different applied treatments on Dry weight (g)/plant at 65 days after sowing during 2016 \& 2017 growing seasons. 
In addition, the calculated assimilation rate (leaf area in $\mathrm{cm}^{2}$ required for producing one gram of dry matter) could support the previously mentioned data about the vigorous growth of squash plants as affected by the applied treatments. Since, it showed its significant reduction proportionally with the two assigned levels of $\mathrm{SCH}, \mathrm{SA}$, $\mathrm{Ca}, \mathrm{Zn}, \mathrm{LRE}$ and GCE. Reduction of assimilation rate could be considered an evidence to increase the efficiency of photosynthesis process and also synthesize more assimilates per each unit of leaf area; hence the high rate of their translocation especially towards sink sites (developing fruits).

Regarding the effect of different applied treatments on squash plants under such cold conditions, it could be concluded that these treatments not only increased the ability of squash plants to withstand the low temperature of the winter surrounding conditions but also induced them to grow well under these adverse conditions. Also, the obtained results showed the superiority of garlic extract, salicylic acid, calcium and cold hardening treatments in descending order than other treatments, i.e., zinc and licorice extract

The promotional effect of low temperature as a seed pre-sowing treatment on the vegetative growth of squash plants under cold stress conditions is in harmony with the findings of Abd El-Dayem et al., (2000). Who mentioned that different low-temperature levels $(-1,-2,-3$ \& -4) applied for 12 or 24 hours as pre-sowing treatments significantly enhanced squash growth parameters expressed as root size, diameter and dry weight, stem length, diameter and dry weight as well as total leaf area and leaves dry weight.

Concerning the stimulatory effect of seed hardening with low temperature on the root growth, it could be attributed to the expected alterations in creating of many constituents as the levels of cytokinins and auxins in which has been recommended to be the main factor for the growth and development of root system (Wien, 1997 and Wanas et al., 1998).

On the other hand, the stimulatory effect of salicylic acid on the growth parameters of squash plants is in agreement with the findings of Abou El-Yazied (2011) who reported that foliar application with SA increased plant height, number of branches and leaves per plant, and leaves dry weight of sweet paper under low temperature on the open field conditions. Also, Mady (2014) mentioned that foliar spray with SA significantly increased all studied growth parameters of squash plants under open field conditions during winter months. This stimulatory effect of SA was accompanied by increased levels of endogenous growth promoters i.e., auxins, gibberellins and cytokinins.

Regarding, the stimulatory effect of the applied nutrient elements ( $\mathrm{Ca}$ and $\mathrm{Zn}$ ) on the vegetative growth parameters coincides with the findings of Wanas (2007a) and Mady (2014). It was established that calcium (Ca) has a growth enhance functions, i.e., activation of cell division and enlargement, synthesis and translocation of bioassimilates which depleted and lacking under stressful conditions (Pereira and Mello, 2002).

As for zinc ( $\mathrm{Zn})$, it was known to evolve an enhancable roles associated with the whole growth activities, particularly during prevailing of the climatic and soil stresses. Zn activates auxins and GAs synthesis, cell division and enlargement (Alphonse, 1996 and Sekimoto et al., 1997), enhances synthesis and translocation of amino acids and sugars (Cakmak and Marschner, 1988 a and Cakmak et al., 1989). Moreover, it displays antioxidantal and gene regulatory functions against environmental stress conditions (Cakmak and Marschner, 1988 b \& c).

Concerning, garlic extract (GCE) suggested to be used for enhancement of IAA, GAs and cytokinins biosynthesis (Wanas et al., 1998), besides its content of nutrients, protein, amino acids, sugars, vitamins, antibiotics, antioxidants... etc. (Mardomi, 2017). So, the enhancement of squash growth under cold stress by using this natural extracts being logically expected due to their high contents of antioxidants, many growth factors and/or their enhancable effect on the endogenous growth hormones, i.e., auxins, gibberellins and cytokinins.

Also, the advantageous effect of licorice root extract may be due to its contents of some nutrients such as phosphorus, potassium, magnesium, iron and zinc and these nutrients play an important role in activation of various enzymes that increase the activity of photosynthesis. Besides, this extract contains mevalonic acid and glycyrrhizin as materials act like gibberellins roles in the plant and increase cell division and elongation (Moses et al., 2002).

\section{2-Photosynthetic pigments:}

Data in Tables (3) represent the mean values $(\overline{\mathrm{X}})$ of chlorophyll a, b \& carotenoids and their sum as well as their increase or decrease values calculated as a percentage $( \pm \%)$ of the control values. Also, data in these Tables indicate that during 2016 and 2017 winter seasons, all applied treatments considerably increased the leaf content of chlorophylls ( $\mathrm{a} \& \mathrm{~b}$ ) and carotenoids as well as their sum at 65 days after sowing compared with the untreated plants. Increases were in parallel to the applied concentrations of SA, Ca, Zn, GCE and LRE, and also to the exposure periods of seed cold hardening, i.e., $12 \& 24$ hours. Besides, the highest values of chlorophyll $\mathrm{a}, \mathrm{b}$ and carotenoids and their sum were obtained with GCE followed by $\mathrm{SA}, \mathrm{Ca}, \mathrm{SCH}, \mathrm{LRE}$ and $\mathrm{Zn}$ in descending order (Table, 3 and Fig., 3).

Other studies reported similar results about the positive responses of photosynthetic pigments to the applied seed cold hardening treatments (Abd El-Dayem et al., 2000 on squash), SA and Ca (Mady, 2014 on squash), Zn (Wanas, 2007a on tomato), GCE (Wanas, 2007b on wheat) and LRE (Al- Jebouri, et al., 2010 on cucumber). 
Wanas, A. L. et al.

Table 3. Effect of seed cold hardening, salicylic acid, calcium, zinc, licorice root extract and garlic extract on photosynthetic pigments (mg/g F.W) of squash leaves at 65 days after sowing (during flowering stage) in both 2016 and 2017 winter seasons.

\begin{tabular}{|c|c|c|c|c|c|c|c|c|c|c|c|}
\hline \multirow{4}{*}{ Treatments } & \multirow{4}{*}{ Characters } & \multicolumn{6}{|c|}{ Chl. } & \multirow{2}{*}{\multicolumn{2}{|c|}{ Carot. }} & \multirow{2}{*}{\multicolumn{2}{|c|}{ Chl. $(\mathbf{a}+\mathbf{b})+$ carot. }} \\
\hline & & \multicolumn{2}{|c|}{$\mathbf{a}$} & \multicolumn{2}{|c|}{$\mathbf{b}$} & \multicolumn{2}{|c|}{$\mathbf{a}+\mathbf{b}$} & & & & \\
\hline & & $\overline{\mathbf{X}}$ & $\pm \%$ & $\overline{\mathbf{X}}$ & $\pm \%$ & $\overline{\mathbf{X}}$ & $\pm \%$ & $\overline{\mathbf{X}}$ & $\pm \%$ & $\overline{\mathbf{X}}$ & $\pm \%$ \\
\hline & & \multicolumn{10}{|c|}{ Season 2016} \\
\hline Control & & 0.467 & 0.00 & 0.401 & 0.00 & 0.868 & 0.00 & 0.416 & 0.00 & 1.284 & 0.00 \\
\hline $\mathrm{SCH}$ & 12 hours & 0.566 & +21.19 & 0.442 & +10.22 & 1.008 & +16.13 & 0.460 & +10.58 & 1.468 & +14.33 \\
\hline$\left(-1^{\circ} \mathrm{C}\right)$ & 24 hours & 0.625 & +33.83 & 0.518 & +29.18 & 1.143 & +31.68 & 0.548 & +31.73 & 1.691 & +31.70 \\
\hline \multirow{2}{*}{ SA } & 100 ppm & 0.582 & +24.63 & 0.465 & +15.96 & 1.047 & +20.62 & 0.442 & +6.25 & 1.489 & +15.97 \\
\hline & 200 ppm & 0.655 & +40.26 & 0.539 & +34.41 & 1.194 & +37.56 & 0.563 & +35.34 & 1.757 & +36.84 \\
\hline \multirow{2}{*}{$\mathrm{Ca}$} & $250 \mathrm{ppm}$ & 0.584 & +25.05 & 0.465 & +15.96 & 1.049 & +20.85 & 0.472 & +13.46 & 1.521 & +18.46 \\
\hline & $500 \mathrm{ppm}$ & 0.668 & +43.04 & 0.538 & +34.16 & 1.206 & +39.52 & 0.562 & +35.10 & 1.768 & +37.69 \\
\hline \multirow{2}{*}{$\mathrm{Zn}$} & $50 \mathrm{ppm}$ & 0.533 & +14.13 & 0.422 & +5.24 & 0.955 & +10.02 & 0.438 & +5.29 & 1.393 & +8.49 \\
\hline & $100 \mathrm{ppm}$ & 0.556 & +19.06 & 0.430 & +7.23 & 0.986 & +13.59 & 0.450 & +8.17 & 1.436 & +11.84 \\
\hline \multirow{2}{*}{ GCE } & $50 \mathrm{~g} / \mathrm{L}$ & 0.640 & +37.04 & 0.512 & +27.68 & 1.152 & +32.71 & 0.475 & +14.18 & 1.627 & +26.71 \\
\hline & $100 \mathrm{~g} / \mathrm{L}$ & 0.693 & +48.39 & 0.543 & +35.41 & 1.236 & +40.67 & 0.563 & +35.34 & 1.799 & +40.10 \\
\hline \multirow{2}{*}{ LRE } & $5 \mathrm{~g} / \mathrm{L}$ & 0.512 & +9.64 & 0.430 & +7.23 & 0.942 & +8.52 & 0.532 & +27.88 & 1.474 & +14.80 \\
\hline & $10 \mathrm{~g} / \mathrm{L}$ & 0.570 & +22.06 & 0.440 & +9.73 & 1.010 & +16.36 & 0.532 & +27.88 & 1.542 & +20.01 \\
\hline & & \multicolumn{10}{|c|}{ Season 2017} \\
\hline Control & & 0.487 & 0.00 & 0.375 & 0.00 & 0.862 & 0.00 & 0.408 & 0.00 & 1.270 & 0.00 \\
\hline $\mathrm{SCH}$ & 12 hours & 0.546 & +12.11 & 0.418 & +11.47 & 0.964 & +11.83 & 0.435 & +6.62 & 1.399 & +10.16 \\
\hline$\left(-1^{\circ} \mathrm{C}\right)$ & 24 hours & 0.611 & +25.46 & 0.520 & +38.67 & 1.131 & +31.21 & 0.572 & +40.20 & 1.703 & +34.09 \\
\hline \multirow{2}{*}{ SA } & $100 \mathrm{ppm}$ & 0.565 & +16.81 & 0.442 & +17.87 & 1.007 & +16.82 & 0.460 & +12.75 & 1.467 & +15.51 \\
\hline & $200 \mathrm{ppm}$ & 0.662 & +35.93 & 0.552 & +47.20 & 1.214 & +40.84 & 0.548 & +34.31 & 1.762 & +38.74 \\
\hline \multirow{2}{*}{$\mathrm{Ca}$} & $250 \mathrm{ppm}$ & 0.562 & +15.40 & 0.438 & +16.80 & 1.000 & +16.01 & 0.462 & +13.24 & 1.462 & +15.12 \\
\hline & $500 \mathrm{ppm}$ & 0.646 & +32.65 & 0.522 & +39.20 & 1.168 & +35.50 & 0.536 & +31.37 & 1.704 & +34.17 \\
\hline \multirow{2}{*}{$\mathrm{Zn}$} & 50 ppm & 0.540 & +10.88 & 0.422 & +12.53 & 0.962 & +11.60 & 0.438 & +7.35 & 1.400 & +10.24 \\
\hline & 100 ppm & 0.568 & +16.63 & 0.436 & +16.27 & 1.004 & +16.47 & 0.486 & +19.12 & 1.490 & +17.32 \\
\hline \multirow{2}{*}{ GCE } & $50 \mathrm{~g} / \mathrm{L}$ & 0.627 & +28.75 & 0.511 & +3627 & 1.138 & +32.19 & 0.540 & +32.35 & 1.678 & +32.13 \\
\hline & $100 \mathrm{~g} / \mathrm{L}$ & 0.684 & +40.45 & 0.560 & +49.33 & 1.244 & +44.32 & 0.573 & +40.44 & 1.817 & +43.07 \\
\hline \multirow{2}{*}{ LRE } & $5 \mathrm{~g} / \mathrm{L}$ & 0.523 & +7.39 & 0.410 & +9.33 & 0.933 & +8.24 & 0.452 & +10.78 & 1.385 & +9.06 \\
\hline & $10 \mathrm{~g} / \mathrm{L}$ & 0.572 & +17.45 & 0.470 & +25.33 & 1.042 & +20.88 & 0.465 & +15.93 & 1.507 & +18.66 \\
\hline
\end{tabular}

Abbreviations: $\mathbf{S C H}=$ Seed cold hardening, $\mathbf{S A}=$ Salicylic acid, Ca $=$ Calcium, $\mathrm{Zn}=\mathrm{Zinc}, \mathrm{LRE}=\mathrm{Licorice}$ root extract, GCE $=\mathrm{Garlic}$ cloves extract and Chl. $=$ Chlorophyll and Carot. $=$ Carotenoids.

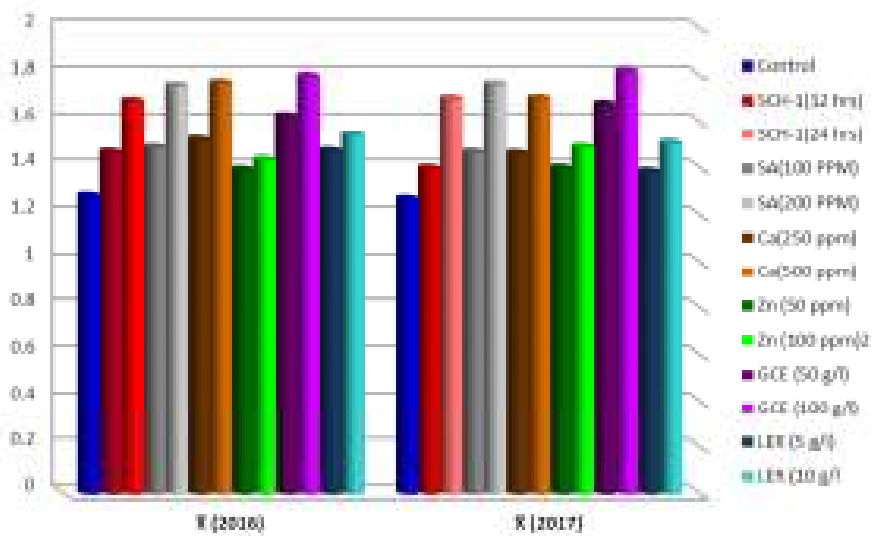

Fig. 3. Shows the effect of different applied treatments on photosynthetic pigments (Chl., a + Chl., b + Carot.) at 65 days after sowing during 2016 \& 2017 growing seasons.

In this respect, Colom and Vazzana (2001) reported that environmental stresses mainly reduce chlorophylls content and this reduction depends upon the plant's genotype. Based on the theory of Schutz and Fangmeirm (2001), the reduction of chlorophylls due to low temperature stress is related to high production of reactive oxygen species (ROS) in cell. These free radicals cause peroxidation disintegration and reduction of chlorophylls content in plants growing under chilling stress.

Herein, the stimulatory effect of SA, Ca and $\mathrm{Zn}$ on photosynthetic pigments might be due to their action as antioxidants, in which protect chloroplasts against the formation of toxic free radicals, thereby prevent degradation of chlorophylls and inhibit the photo-oxidation of these pigments that arise under stressful conditions (Aono et al., 1993).
Regarding the pronounced effect of garlic extract (GCE) suggested to participate a beneficial role during vegetative growth through enhancement the chlorophyll formation, photosynthetic efficiency and biosynthesis of IAA, GAs and cytokinins (Wanas et al., 1998). Moreover, garlic cloves are highly rich in antioxidants as phenolic compounds, vitamins and flavonoids (Lanzotti et al., 2014 and Mardomi, 2017) which play an important role in protecting chloroplasts against the toxic free radicals that arise under such cold stress conditions, thereby prevent degradation of chlorophylls and inhibit the photo-oxidation of these pigments (Lanzotti et al., 2014).

As for the enhancable effect of licorice root extract (LRE) on the leaf content of photosynthetic pigments, it might be due to its content of mevalonic acid which is the initiator in the biosynthesis of $\mathrm{GA}_{3}$ in plant (Al-Jebouri, et 
al., 2010). GAs have been established to induce the biosynthesis of chloroplast pigments in many plants (Wareing, \& Phillips, 1981; Wanas, 1992 and Wanas et al., 1998).

3- Chemical constituents in leaves:

Data in Tables (4) clearly show that the two applied exposure periods of $\mathrm{SCH}$ at $-1{ }^{\circ} \mathrm{C}$ as a seed pre-sowing treatments as well as the two concentrations used of each of SA, Ca, Zn, CGE and LRE obviously increased N, P, $\mathrm{K}, \mathrm{Ca}$ and $\mathrm{Mg}$ concentrations in leaves of treated plants at 65 days after sowing during the two growing seasons compared with those of the untreated plants.

Also, total sugars and carbohydrates, as well as crude protein, were positively responded to all applied treatments. Again, increases were in parallel to the applied concentration of SA, Ca, Zn, GCE and LRE and also to the exposure period of seed hardening at $-1{ }^{0} \mathrm{C}$, i.e., $12 \& 24$ hours. Moreover, the highest values were mostly obtained with GCE at $100 \mathrm{~g} / 1$ followed by SA at $200 \mathrm{ppm}, \mathrm{Zn}$ at 100 ppm, LRE at $10 \mathrm{~g} / \mathrm{l}, \mathrm{Ca}$ at $500 \mathrm{ppm}$ and $\mathrm{SCH}$ at $-1^{\circ} \mathrm{C}$ for 24 hours of exposure period in descending order.

Other studies reported similar results about the positive responses of the estimated minerals and bioconstituents to the applied seed cold hardening treatments (Abd El-Dayem et al., 2000 on squash), SA and Ca (Mady, 2014 on squash), Zn (Wanas, 2007a on tomato), GCE (Wanas, 2007b on wheat) and LRE (Matter, et al., 2012 on potato).

Regarding the enhancement of the applied treatments upon the minerals content, it could be considered as a direct effect of these treatments upon stimulating their absorption through vigorous root system of the treated plants (Tables, $1 \& 2$ ), Besides, increases of the leaf area (Tables, $1 \& 2$ ), and photosynthetic pigments (Table, 3), as well as increment of the dry matter accumulation in leaves, indicate the positive and stimulatory effects of the applied treatments upon the efficiency of photosynthesis process, hence more photosynthates, such as sugars, being created as well as enhancement of mineral translocation from roots to leaves. In addition, increased sugars in the cell are thought to have a number of roles in improving cold tolerance. Sugars are thought to associate with the membrane of the cell by replacing lost water and maintaining membrane fluidity. Also, sugars play a role as energy sources and building blocks for other cold important cold tolerance processes in the cell (McKnow et al., 1996). Moreover, sugars link to the case of cold tolerance via their roles as cellular cryoprotective or osmoregulator agent (Hockaka and Somero, 1973), they in conjugation with dehydrin proteins and cold-regulated proteins act to stabilize both membrane phospholipids and proteins and cytoplasmic proteins against denaturations induced by cold stress as well as scavenge the reactive oxygen species (Gusta, 2004 and Chen and Murata, 2008). Furthermore, phosphorus uptake and level depressed by low temperature (Table, 5) known to be taken as an indicator of energy status, so its level directly associated with cold tolerability or sensitivity.

Table 4.Effect of seed cold hardening, salicylic acid, calcium, zinc, garlic extract and licorice root extract on some chemical constituents of squash leaves at 65 days after sowing (during flowering stage) in both 2016 and 2017 winter seasons.

\begin{tabular}{|c|c|c|c|c|c|c|c|c|c|c|c|}
\hline \multirow[b]{3}{*}{ Treatmen } & \multirow[t]{2}{*}{ Determinations } & \multicolumn{7}{|c|}{ mg/g D.W. } & \multicolumn{3}{|c|}{ mg/g F.W. } \\
\hline & & $\mathbf{N}$ & $\mathbf{P}$ & $\mathbf{K}$ & $\mathbf{C a}$ & Mg & $\begin{array}{c}\text { Crud } \\
\text { protein }\end{array}$ & $\begin{array}{l}\text { Total } \\
\text { carb. }\end{array}$ & $\begin{array}{c}\text { Red. } \\
\text { sugars }\end{array}$ & $\begin{array}{c}\text { Non-red. } \\
\text { sugars }\end{array}$ & $\begin{array}{c}\text { Total } \\
\text { sugars }\end{array}$ \\
\hline & & \multicolumn{10}{|c|}{ Season 2016} \\
\hline$\overline{\text { Control }}$ & & 25.15 & 2.38 & 24.70 & 28.55 & 7.45 & 157.25 & 504.18 & 6.70 & 3.55 & 10.25 \\
\hline $\mathrm{SCH}$ & 12 hours & 28.85 & 2.68 & 26.68 & 30.85 & 8.68 & 180.31 & 533.52 & 8.18 & 4.70 & 12.88 \\
\hline$\left(-1^{\circ} \mathrm{C}\right)$ & 24 hours & 32.90 & 2.95 & 27.95 & 31.12 & 9.28 & 205.63 & 552.28 & 8.92 & 5.12 & 14.04 \\
\hline \multirow{2}{*}{ SA } & $100 \mathrm{ppm}$ & 32.15 & 3.08 & 27.98 & 31.58 & 8.78 & 200.94 & 565.68 & 8.75 & 4.95 & 13.70 \\
\hline & $200 \mathrm{ppm}$ & 34.12 & 3.55 & 28.85 & 33.28 & 9.88 & 213.25 & 596.25 & 10.12 & 5.98 & 16.10 \\
\hline \multirow{2}{*}{$\mathrm{Ca}$} & $250 \mathrm{ppm}$ & 30.88 & 2.78 & 26.95 & 33.68 & 8.72 & 193.00 & 538.62 & 8.38 & 4.62 & 13.00 \\
\hline & $500 \mathrm{ppm}$ & 32.42 & 3.18 & 28.18 & 36.18 & 9.45 & 202.63 & 573.92 & 9.40 & 5.28 & 14.68 \\
\hline \multirow{2}{*}{$\mathrm{Zn}$} & $50 \mathrm{ppm}$ & 31.72 & 2.90 & 27.42 & 31.48 & 8.58 & 198.25 & 546.48 & 8.52 & 4.82 & 13.34 \\
\hline & $100 \mathrm{ppm}$ & 34.08 & 3.48 & 28.68 & 32.95 & 9.62 & 213.00 & 600.72 & 9.75 & 5.68 & 15.43 \\
\hline \multirow{2}{*}{ GCE } & $50 \mathrm{~g} / \mathrm{L}$ & 33.15 & 3.22 & 28.28 & 33.08 & 8.98 & 207.19 & 582.35 & 9.65 & 5.45 & 15.10 \\
\hline & $100 \mathrm{~g} / \mathrm{L}$ & 36.68 & 3.98 & 29.68 & 35.28 & 10.08 & 229.25 & 608.88 & 10.90 & 6.40 & 17.30 \\
\hline \multirow{2}{*}{ LRE } & $5 \mathrm{~g} / \mathrm{L}$ & 31.12 & 2.92 & 27.32 & 31.18 & 8.55 & 194.50 & 548.42 & 8.70 & 4.82 & 13.52 \\
\hline & $10 \mathrm{~g} / \mathrm{L}$ & 33.35 & 3.35 & 28.55 & 32.48 & 9.52 & 208.44 & 586.62 & 9.92 & 5.92 & 15.84 \\
\hline \multirow{2}{*}{\multicolumn{2}{|c|}{ Control }} & \multicolumn{10}{|c|}{ Season 2017} \\
\hline & & 23.92 & 2.50 & 23.95 & 28.22 & 7.18 & 149.50 & 481.12 & 6.38 & 3.42 & 9.80 \\
\hline $\mathrm{SCH}$ & 12 hours & 26.68 & 2.82 & 27.10 & 30.45 & 8.38 & 166.75 & 514.32 & 7.85 & 4.65 & 12.50 \\
\hline$\left(-1^{\circ} \mathrm{C}\right)$ & 24 hours & 29.90 & 3.08 & 28.42 & 30.92 & 9.20 & 186.89 & 530.52 & 8.70 & 5.10 & 13.80 \\
\hline \multirow{2}{*}{ SA } & $100 \mathrm{ppm}$ & 29.80 & 3.12 & 28.38 & 31.10 & 8.42 & 186.25 & 558.40 & 8.52 & 4.82 & 13.34 \\
\hline & $200 \mathrm{ppm}$ & 31.22 & 3.72 & 29.12 & 32.62 & 9.78 & 195.13 & 582.80 & 9.75 & 5.82 & 15.57 \\
\hline \multirow[b]{2}{*}{$\mathrm{Ca}$} & $250 \mathrm{ppm}$ & 28.58 & 2.95 & 27.42 & 33.28 & 8.20 & 178.63 & 520.72 & 8.20 & 4.45 & 12.65 \\
\hline & $500 \mathrm{ppm}$ & 29.95 & 3.15 & 28.45 & 35.92 & 9.12 & 187.19 & 554.92 & 9.10 & 5.12 & 13.22 \\
\hline \multirow{2}{*}{$\mathrm{Zn}$} & $50 \mathrm{~g} / 1$ & $29 . .85$ & 3.05 & 28.08 & 31.05 & 8.38 & 186.56 & 533.18 & 8.45 & 4.60 & 13.05 \\
\hline & $100 \mathrm{~g} / 1$ & 30.78 & 3.38 & 28.82 & 32.40 & 9.22 & 192.38 & 592.12 & 9.62 & 5.38 & 15.00 \\
\hline \multirow{2}{*}{ GCE } & $50 \mathrm{~g} / \mathrm{L}$ & 29.95 & 3. 18 & 29.10 & 32.70 & 8.72 & 187.19 & 568.40 & 9.22 & 5.28 & 14.50 \\
\hline & $100 \mathrm{~g} / \mathrm{L}$ & 32.18 & 3.82 & 30.25 & 34.65 & 9.65 & 201.13 & 596.68 & 10.50 & 6.32 & 16.82 \\
\hline \multirow{2}{*}{ LRE } & $5 \mathrm{~g} / \mathrm{L}$ & 28.82 & 298 & 27.52 & 30.60 & 8.28 & 180.25 & 534.20 & 8.40 & 4.62 & 13.02 \\
\hline & $10 \mathrm{~g} / \mathrm{L}$ & 30.12 & 3.25 & 28.68 & 31.72 & 9.35 & 188.25 & 570.25 & 9.78 & 5.68 & 15.46 \\
\hline
\end{tabular}

Abbreviations: $\mathbf{S C H}=$ Seed cold hardening, $\mathbf{S A}=$ Salicylic acid, $\mathbf{C a}=$ Calcium, $\mathrm{Zn}=$ Zinc, $\mathbf{L R E}=$ Licorice root extract, $\mathbf{G C E}=\mathbf{G a r l i c}$ cloves extract, Red. $=$ Reducing and carb. $=$ carbohydrates.

As for calcium, it has many important roles in plants as: an osmoticum within vacuoles; a stabilizing element of membranes; a strengthening agent in cell walls and a secondary messenger in signal transduction system and gene expression alteration during stress (Dodd et al., 2010 and Cacho et al., 2013).

Hence, it could be concluded that the applied treatments, especially SA, GCE and LRE significantly enhanced the vegetative growth of squash plants under 
cold conditions accompanied with high efficiency of photosynthesis process and minerals uptake. This could be reflected upon the further growth stages and lead to achieve more fruits yield with good quality. Therefore, the present study strongly admit the use of natural garlic and licorice extracts, salicylic acid and some mineral nutrients as seed pre-sowing and foliar spray treatments not only to improve growth and productivity of squash plants during winter months under outdoors conditions, but also to avoid all cautions (regarding both environment and human health) for inserting greenhouses production in the agricultural system.

\section{REFERENCES}

A.O.A.C. (1990): Official Methods of Analysis, 15th Ed., Association of Official Analytical Chemists, Washington DC, USA.

Abd El-Dayem, A.M.; Wanas, A.L. and Mady, M.A. (2000): Effect of Low Temperature on Growth and Fruit Yield and Quality of Squash (Cucurbita pepo, L.) Plant. Egypt. J. Appl. Sci., 15(10): 19-32.

Abou El-yazied, A. (2011): Effect of foliar application of salicylic acid and chelated zinc on growth and productivity of sweet paper (Capsicum annuиm, L.) under autumn planting. Res. J. Agric. Sci., 7(6): 423433.

Al-Jebouri, K. A.; Al-Rekabee, A. and Hasoon, W. H. (2010): Role of spraying with some plant extracts in flowering of cucumber in plastic houses. Iraqi $\mathrm{J}$. Agric. Sci., 41(1): 111- 120.

Almehmedi. A. F.; Nasralla, A. Y. and Anna, S. (2011): Effect of licorice, fenugreek extracts and $\mathrm{GA}_{3}$ on yield of caraway (Carum carvi, L.). Iraqi J. Desert Studies, 3 (1): 27-42.

Alphonse, M. (1996): Effect of low temperature, zinc and gibberellic acid (GA3) on the growth, flowering, earliness, yield and protein of pea (Pisum sativum, L.) Alex. J. Agric. Res., 41 (3): 367 - 377.

Aono, M.; Kubo, A.; Saji, H. Tanaka, K. and Kondo, N. (1993): Enhanced tolerance in photo-oxidative stress transgenic (Nicotiana lahaci) with high chloroplastic glutathione reductase activity. Plant Cell Physiol., 34: 129-135.

Arystanova, T.; Irismetov, M. and Sophekova, A. (2001): Chromatographic determination of Glycyrrhizinic acid in Glycyrrhiza glabra preparation. Chem. Nat. Com., 37: 89-91.

Cacho, M.; Dominguez, A.T. and Elena-Rossello, J. (2013): Role of polyamines in regulating silymarin production in Silybum marianum (L.) Gaertn (Asteraceae) cell cultures under conditions of calcium deficiency. J Plant Physiol., (170): 1344 1348.

Cakmak, I. and Marschner, H. (1988a): Increase in membrane permeability and exudation in roots of Zn-deficient plants. J. Plant Physiol., 132: 356 - 361.

Cakmak, I. and Marschner, H. (1988b): Enhanced superoxide radical production in roots of $\mathrm{Zn}$ deficient plants J. Exp. Bot., 39: 1449 - 1460.

Cakmak, I. and Marschner, H. (1988c): Zinc dependent changes in ESR signals, NADPH oxidase and plasma membrane permeability. Physiol. Plant., 73: $132-136$.

Cakmak, I. and Marschner, H. (1992): Magnesium deficiency and high light intensity enhance activities of superoxide dismutase and ascorbate peroxidase and glutathione reductase in bean leaves. Plant Physiol., 93: 1222-1227.
Cakmak, I., Marschner, H. and Bangerth F. (1989): Effect of zinc nutritional status on growth, protein metabolism and levels of IAA and other phytohormones in bean. J. Exp. Bot., 40: 405 - 412.

Colom, M. R. and Vazzana, C. (2001): Drought stress effect on three cultivars of Eragrostis curvula photosynthesis and water relation. J. Plant Growth Regul., 34: 195-202.

Chen, Z. H. and Murata, N. (2008): Glycine betaine: an effective protectant against abiotic stressin plants. Trends in Plant Sci., (3): 1883-1886.

Derieux, M.; Kerrest, R. and Montalon, Y. (1973): Etude de la sulface foliare et de L' activite photosynthetique chez qulques hybrides de mais. Ann. Amelior Plantes, 23: 95 - 107.

Dikinson, C.D.; Altabella, T. and Chrispeel. M.J. (1991): Slow - growth phenotype of transgenic tomato expressing apoplastic invertase. Plant Physiol., 95: 420-425.

Dodd, A.N.; Kudla, J. and Sanders, D. (2010): The language of calcium signaling. Annual Review of Plant Biology, (61): 593-620.

Dubois, M.; Gilles, K. A; Hamilton, J. K.; Rebens, P. A. and Smith, F. (1956): Colorimetric method for determination sugars and related substances. Anal Chem., 28: 350 - 356 .

El-Desouky, S.A.; Wanas, A.L. and Khedr, Z.M.A. (1988): Utilization of some natural plant extracts (of garlic and yeast) as seed-soaked materials to squash (Cucurbita pepo, L.) 1-Effect on growth, sex expression and fruit yield and quality. Ann. Agric. Sci., Moshtohor, Zagazig Univ., 25(2): 839-854.

Elmastas, M.; Gulcin, I.; Isildak, O.; Kufervioglu, O.I.; Ibaogluand, K. and Enein, H.Y.A. (2006): Radical scavenging activity and antioxidant capacity of bay leaf extract. J. Iran Chem. Soc., 3: 258-266.

Faraj, F. M. A. and Ghaloom, A. A. A. (2012): Effect of licorice extract on growth and yield in onion plants cv. Texas Grano. Diyala Agriculture Science Journal, 4(1): 140-147.

Fathy, El-S. L.; Farid, S. and El-Desouky, S.A. (2000): Induce cold tolerance of outdoor tomatoes during early summer season by using adenosine triphosphate (ATP), yeast, other natural and chemical treatments to improve their fruiting and yield. J. Agric. Sci. Mansoura Univ., 5(1): 377-401.

Gusta, L. V.; Wisniewski, M.; Nisbitt, N. T. and Gusta, M. L. (2004): The effect of water, sugars and proteins on the patterns of ice nucleation and propagation in acclimated and nonacclimated canola leaves. Plant Physiol., (135): 1642-1653.

Hanson, H.C. and Churchill, E.D, (1968): The Plant Community. $3^{\text {rd }}$ Printing Rcinhold Pub.

Horneck, D. A. and Hanson, D. (1998): Determination of potassium and sodium by Flame spectrophotometry. In: Handbook of Reference Methods for Plant Analysis. Kalra, Y.P. (Ed.): 153-155.

Horneck, D. A. and Miller, R.O. (1998): Determination of total nitrogen in plant tissue. In: Handbook of Reference Methods for Plant Analysis. Kalra, Y.P. (Ed.): 75-83.

Hockaka, P.W. and Somero, G.N. (1973): Increased chilling tolerance by using some minerals nutrients for cucumber seedlings. Egypt J. Hort., 20 (2): 243 256.

Jackson, L. M. (1967): Soil Chemical Analysis. Prentice Hallpvt Itd. India, pp.: 398.

Khan, W.; Prithiviraj, B. and Smith, D. (2003): Photosynthetic response of corn and soybean to foliar application of salicylates. J. Plant Physiol., (160): 485-492. 
Klessing, D.F, and Malamy, J. (1994): The salicylic acid signal in plants. J. Plant Mol. Biol., 26: 1439-1458.

Lanzotti, V., Scala, F., \& Bonanomi, G. (2014): Compounds from Allium species with cytotoxic and antimicrobial activity. Phytochemistry Reviews, 13: 769-791.

Lukatkin, S.; razaityte,A.; Bobinas,C. and Duchovsiks, P. (2012): Chilling injury in chilling-sensitive plants: A Review Agric., 99(2): 111-124.

Mady, M.A. (2014): Inducing cold tolerability in squash (Cucurbita pepo, L.) plant by using salicylic acid and chelated calcium application. International J. Agric. Sci. and Res.(IJASR), 4(4): 9-24.

Mardomi R. (2017): Determining the Chemical Compositions of Garlic Plant and its Existing Active Element. IOSR Journal of Applied Chemistry (IOSR-JAC) e-ISSN: 2278-5736.Vol.10, Issue 1 Ver. I (Jan. 2017), pp. 63-66.4.

Marschner, H. (1995): Mineral Nutrition of Higher Plants. Academic Press, Horcol Brace and Company Pub, London San Diego, New York, pp 379.

Matter, H. M.; Saad, A. M and Ahmad, F. R. (2012): Effect of the treatment by gibberellic acid and liqourice extract on growth and yield of potato. J. Diyala., 4(1): 220-234.

Mckerise, B. O.; Bowley, S. R.; Harjanio, E and Lepnnce, O. (1996): Water deficit tolerance and field performances of transgenic alfalfa over expressing superoxide dismutase. Plant Physiol., 111: 11701181.

McKnow, R.; Kuroki, G. and Warren, G. (1996): Cold responses of Arabidopsis mutants impaired in freezing tolerance. J. Exp. Bot., (47): 1919-1925.

Moses, T. N. A.; Wheeb, W.; Al- Hadithy, Z. and Ellewy, A. N. (2002): Studying some components of the local licorice (Glycyrrhiza glabra, L.) roots powder. J. Agric. Sci. Iraqi. 34(4): 30-38.

Palva, E.T. (1993): Gene expression under low temperature stress. pp. 103-130 in: Stress Induced Gene Expression in Plants. A.S. Basra (ed.), Newark N.J.; Harwood.

Pereira, H. S. and Mello, S. C. (2002): Foliar fertilizer applications effects in nutrition and yield of sweet pepper and tomato. Brasilia, 20 (4): 597-600.

Rab, A. and Saltveit, M.E. (1996): Sensitivity of seedling radicles to chilling and heat - shock induced chilling tolerance. J. Amr. Soc. Hort. Sci., 121(4): 711-715.

Rossi, I. (1999): Medicinal Plants of the World. Vol. 2: Chemical constituents traditional and modern medicinal uses. Human Press, USA.

Sandell, R. (1950): Colorimetric determination of traces of metal. $2^{\text {nd }}$ Ed., Interscience Publishers, Inc., New Yourk.
Schutz, M. and Fangmeir E. (2001): Growth and yield response of spring wheat (Triticum aestivum, L. cv. Minaret) to elevated $\mathrm{CO}_{2}$ and water limitation. Environ, Polut., 11: 187-194.

Seham, M.M. Aly (2002): Effect of some Agriculture treatments on yield productivity of squash. Ph.D. Thesis, Fac. of Agric., Moshtohor, Zagazig Univ.

Sekimoto, H.; Hoshi, M.; Nomura, T. and Yokota, T. (1997): Zinc defficiency affects the levels of endogenous gibberellins in Zea mays. Plant and Cell Physiol., 38 (9): 1087 - 1090.

Snedecor, G.W. and Cochran, W.G. (1989): Statistical Methods $8^{\text {th }}$ Ed., Iowa State Univ. Press., Ames. Iowa, USA.

Schutz, M. and Fangmeirm E. (2001): Growth and yield response of spring wheat (Triticum aestivum, L. cv. Minaret) to elevated $\mathrm{CO}_{2}$ and water limitation. Environ, Polut., 11: 187-194.

Thomas, W. and Dutcher, R. A. D. (1924): The colorimetric determination of carbohydrates methods. J. Amer. Chem. Soc., 46: 1662 - 1669 .

Ulsusomiya, E. and Muto, S. (1993): Carbonic anhydrase in the plasma membranes from leaves of $\mathrm{C} 3$ and $\mathrm{C} 4$ plants. Physiol. Plant., 88: 413-419.

Vallee, B. L. and Auld, D. S. (1990): Zinc coordination, function and structure of zinc enzymes and other proteins. Biochemistry, 29: 5647-5659.

Wanas, A. L. (1992): Botanical Studies on Some Members of Fabaceae Family. M. Sc. Thesis, Fac. of Agric., Moshtohor, Zagazig Univ.

Wanas, A.L. (2006): Response of squash plants grown in winter season to some natural extracts and antioxidants. Annals Agric. Sci., Moshtohor, 44(4): 1571-1591.

Wanas, A.L. (2007a): Trials for improving growth and productivity of tomato plants grown in winter. $\mathrm{J}$. Agric. Sci., Mansoura Univ., 32(2): 991-1009.

Wanas, A.L. (2007b): Effect of some natural extracts and benzyladenine on growth and productivity of wheat plants. J. Agric. Sci., Mansoura Univ., 32(2): 10111029.

Wanas, A.L.; El-Desouky, S.A. and Khedr, Z.M. (1998): Utilization of some natural plant extracts (of garlic and yeast) as seed-soaked materials to squash (Cucurbita pepo, L.). II-Effects on the Histological features and the endogenous hormones. Ann. Agric. Sci. Moshtohor, Zagazig Univ., 35(2): 855-878.

Wareing, P.E. and Phillips, I.D.J. (1981): Growth and Differentiation in Plants. 3rd Ed., Pergamon Press, Oxford.

Wien, H.C. (1997): The cucurbits: Cucumber, Melon, Squash and Pumpkin: in the Physiology of vegetable crops.CAB International, H.C. Wien (ed.), pp. 345386.

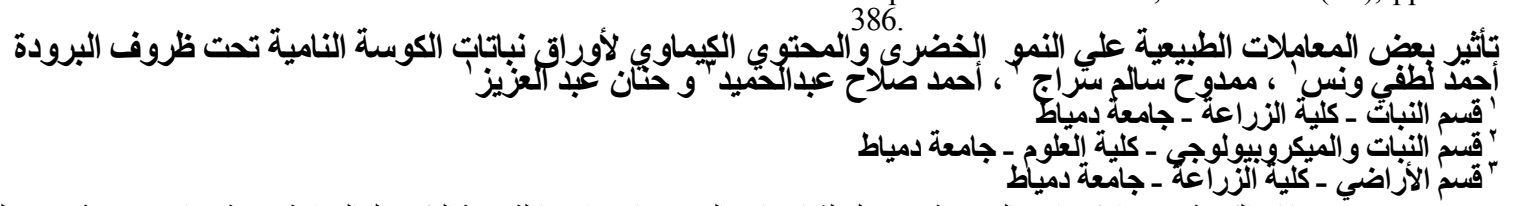

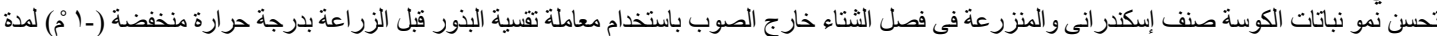

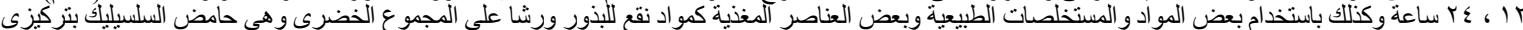

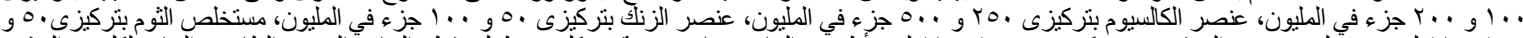



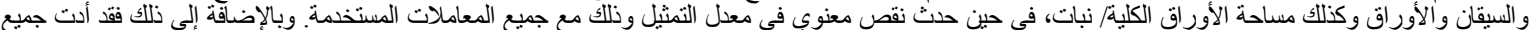



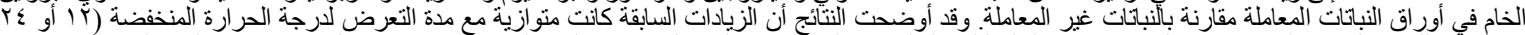

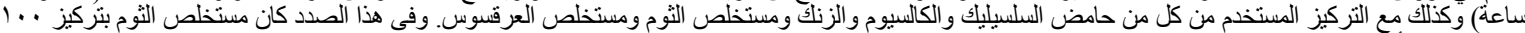



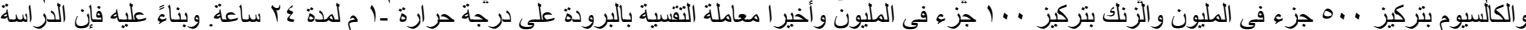

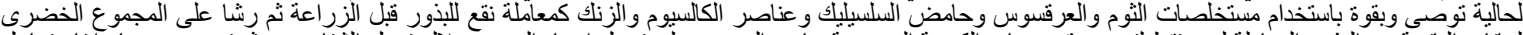

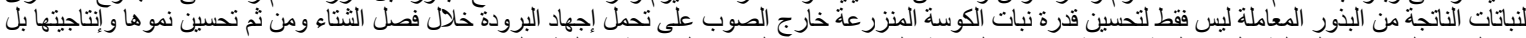

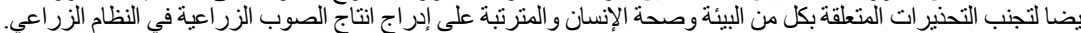

